\title{
The European Public Prosecutor's Office: How Should the Rules Applicable to its Procedure be Determined?
}

\author{
Katalin Ligeti ${ }^{\star}$
}

\begin{abstract}
The fact that the European Public Prosecutor's Office is provided for in the Treaty is undoubtedly a very important step. At the same time, Art. 86 TFEU is one of the most delicate provisions of the new Treaty. It is sensitive both from a political and a legal point of view: The establishment of the EPPO - both because of its strong symbolic value and because of the potential powers it may have - clearly challenges Member States' sovereignty and the powers, institutional organisation and realistic aspirations of existing EU criminal justice bodies. On the other hand, from the legal point of view, its implementation raises a list of questions without straightforward answers. The present article shall start with an overview of the history of the EPPO followed by a brief analysis of the legal confines of Art. 86 TFEU and the policy debates linked to it. In order to assess the implementation of the EPPO, the policy, institutional and legislative developments in the Area of Freedom, Security and Justice will be described. Special attention will be paid to the advocated role of mutual recognition. Based on the preliminary findings of the comparative study on the "EU model rules of criminal investigation and prosecution for the procedure of the proposed European Public Prosecutor's Office" conducted by the author, it will be argued that the EPPO may rely on mutual recognition only to a limited extent.
\end{abstract}

\section{The history of the European Public Prosecutor}

The idea of a European Public Prosecutor (EPP) was first mentioned in the Corpus Juris in 1997. In the interim, there have been four models suggested for establishing the EPPO. These models shall be examined in the following with the aim to determining the rules applicable to the procedure of the future EPPO.

\section{The concept of the Corpus Juris}

Since the 1980s, the protection of the EC's financial interests and the administrative and criminal law response to EC fraud has been a key issue on the political agenda of the EC/EU. Due to the pressure of the European Parliament and public opinion, in 1988 the Commission established an anti -fraud unit, $\mathrm{UCLAF}^{2}$ - the predecessor of OLAF - and adopted a set of instruments to confer administrative investigation powers on that body. Parallel to this, negotiations started at EU level on the proper protection of the financial interests of the EU and in 1995, the

\footnotetext{
${ }^{\star}$ Professor of European and international criminal law, University of Luxembourg.

${ }^{1}$ Comparative law study financed by the EU Commission in the framework of the Hercule II Programme.

${ }^{2}$ Unité de coordination de la lutte anti-fraude.
} 
Member States had accepted a package of respective Third Pillar instruments ${ }^{3}$ (including the PIF Convention and its protocols).

Due to the difficult establishment of the Third Pillar and the slowness and relative unwillingness of Member States to ratify the agreements adopted in the Third Pillar, the European Parliament asked the European Commission to carry out a study on the possibilities of harmonising criminal law and criminal procedures in view of an effective protection of the EC's financial interests. The result - the Corpus Juris $1997^{4}$ - was finalised, after an implementation study, in the Corpus Juris $2000^{5}$. The most revolutionary parts of the Corpus Juris are undoubtedly those on the establishment of a European Public Prosecutor (EPP) and on the harmonisation of criminal procedure.

The Corpus Juris' main proposal was to establish a new body within the European Community institutions - the European Public Prosecutor (EPP) - that would be responsible for the investigation and prosecution of crimes against the EU's financial interests. According to the Corpus Juris, the EPP shall be an authority of the European Community that consists of a European Director of Public Prosecution (EDPP) and European Delegated Public Prosecutors (EDelPPs). ${ }^{6}$ The role of the EDPP would be to oversee and coordinate investigations and delegate them to EDelPPs (based in the Member States) who would play the main part in conducting investigations, although the EDPP may exercise all powers himself. ${ }^{7}$ The relation between members of the EPP is described by rules of independence from national authorities and Community institutions ${ }^{8}$, indivisibility and interdependence. ${ }^{9}$ These rules are completed by the obligation of the national public prosecutors to assist the EPP. ${ }^{10}$ According to this concept, the trial in the first instance as well as the appeal is held before national courts according to national criminal procedures. ${ }^{11}$

According to the Corpus Juris, the EPP's responsibility consists in "investigation, prosecution, committal to trial, presenting the prosecution case at trial and the

\footnotetext{
${ }^{3}$ Convention of $26^{\text {th }}$ July on the protection of the financial interests of the European Communities' financial interests, OJ No. C 316, $27^{\text {th }}$ November, 1995, p. 49; Protocol of $27^{\text {th }}$ September, 1996, to the Convention on the protection of the European Communities' financial interests, OJ No. C 313, 23 ${ }^{\text {rd }}$ October, 1996, p. 2; Protocol of $29^{\text {th }}$ November, 1996, on the interpretation, by way of preliminary rulings, by the Court of Justice of the European Communities of the Convention on the protection of the European Communities' financial interests, OJ No. C 151, $20^{\text {th }}$ May, 1997, p. 1; Second Protocol of $19^{\text {th }}$ June, 1997, to the Convention on the protection of the European Communities' financial interests, OJ No. C 221, $19^{\text {th }}$ July, 1997, p. 12; Convention of $26^{\text {th }}$ May, 1997, on the fight against corruption involving officials of the European Communities or officials of Member States of the European Union, OJ No C $195,25^{\text {th }}$ June, 1997, p. 2; Council regulation of $28^{\text {th }}$ December, 1995 on the protection of the European communities' financial interests, OJEC No L312, 23 ${ }^{\text {rd }}$ December, 1995, p. 1.

${ }^{4}$ M. Delmas-Marty (ed.), Corpus juris portant dispositions pénales pour la protection des intérêts financiers de l'Union européenne, Economica, 1997.

${ }^{5}$ M. Delmas-Marty/J.A.E. Vervaele (eds.), The Implementation of the Corpus Juris in the Member States, Intersentia 2000, v. I, Intersentia, Antwerp 2000.

${ }^{6}$ Art. 18.3, Appendix III: Corpus Iuris 2000 in: M. Delmas-Marty/J. A. E. Vervaele (eds.), The Implementation of the Corpus Juris in the Member States, Intersentia 2000, v. I, Intersentia, Antwerp 2000.

${ }^{7}$ Art. 20.2 and 20.3, Appendix III, op. cit.

${ }^{8}$ Art. 18.2 and Implementing provision to Article 18 Appendix III, op. cit.

${ }^{9}$ Art. 18.4, Appendix III, op. cit.

${ }^{10}$ Art. 18.5, Appendix III, op. cit.

${ }^{11}$ Art. 26.1 and 27.1, Appendix III, op. cit.
} 
execution of sentences" concerning the offences falling in its remit. ${ }^{12}$ The authors of the CJ have chosen the continental approach to the role of the prosecutor, thus he should look for "evidence of innocence as well as evidence of guilt". ${ }^{3}$ Consequently, the EPP should have the following investigation powers:

- questioning of the accused,

- collection of documents and/or computer-held information necessary for the investigation and, if need be, visits to the scene of the offence,

- request addressed to the judge to order an expert enquiry,

- searches, seizures and telephone tapping,

- hearings of witnesses who agree to cooperate with the law and, as may be, witnesses obliged to appear,

- notification of charges to the accused,

- to make requests for a person's remand in custody or judicial control, ${ }^{14}$

- summoning of a person to appear "when he has reasons to believe that he possesses information which might be useful to his investigation". 15

These powers may be exercised by the EDPP or delegated to the EDelPP, who in turn may partially subdelegate it to a national authority for a limited period and in respect of a particular matter. ${ }^{16}$

It is important to note that even though the Corpus Juris contained a set of criminal procedural rules, it was not meant to be a code of criminal procedure. ${ }^{17}$ It was designed as a concept paper focusing on vertical integration and offering a way forward to policy makers at European and national level. Therefore, the Corpus Juris did not contain any details or implementing provisions on the above investigation measures. It only fleshed out a set of investigation powers which should be regulated at the supranational level. Furthermore, it provided for a certain harmonisation of the admissibility of evidence. ${ }^{18}$

In order to enable the work of the EPP as a supranational body, the Corpus Juris provided for the harmonisation of criminal procedure concerning the pre-trial stage of the proceeding based on three governing principles: European territoriality, due process in criminal proceedings and adversarial proceedings. With a view to the different legal traditions of the Member States, the Corpus Juris endeavoured to create a symbiosis between common law criminal procedure and continental criminal procedure.

According to the principle of European territoriality, the decisions of the EPP as well as of the national prosecutors pursuant to the Corpus Juris may be issued

\footnotetext{
${ }^{12}$ Art. 18.2, Appendix III, op. cit.

${ }^{13}$ Art. 20.1, Appendix III, op. cit.

${ }^{14}$ Art. 20.3, Appendix III, op. cit.

${ }^{15}$ Art. 20.3(e), Appendix III, op. cit.

${ }^{16}$ Art. Art. 20.4, Appendix III, op. cit.

${ }^{17}$ M. Delmas-Marty/J. A. E. Vervaele (eds.), The Implementation of the Corpus Juris in the Member States, op. cit. p. V.

${ }^{18}$ Art. 20 (rules for certain types of evidence) and 32 (admissibility of evidence), Appendix III: Corpus Iuris 2000 in: M. Delmas-Marty/J.A.E. Vervaele (eds.), The Implementation of the Corpus Juris in the Member States, Intersentia 2000, volume I.
} 
and are valid in all the Member States and the EPP has competence to investigate and prosecute in the territory of all the Member States treated as a single area, which is referred to by the authors as the European judicial area. Moreover, the warrants issued by the judge of freedoms as well as the judgments are enforceable throughout this territory. ${ }^{19}$ Pursuant to the principle of European territoriality, acts issued according to the rules of the Corpus Juris shall be executed directly in accordance with the rules concerning the cooperation between the EPP and national bodies.

The principle of European territoriality is not only expressed as one of the governing rules of the Corpus Juris but is also enshrined in its various provisions. First of all, any EDelPP may act in any regardless of the country where s/he is delegated $^{20}$ and all members of the EPP who have been appointed by the EDPP for the purposes of the prosecution and investigation are competent in the whole territory of the European Union. ${ }^{21}$

Besides having made reference to the European Convention on Human Rights, the authors of the Corpus Juris provided for a great number of provisions guaranteeing due process in criminal proceedings as well as a list of rules guaranteeing defence rights. Hence, the Corpus Juris included into its set of principles, the principle of judicial guarantee that requires that the accused may be found guilty only by an independent and impartial tribunal and expect that pre-trial measures seriously affecting a person's liberties be authorised by a judge with the same qualities. ${ }^{22}$ This rule is repeated in the provisions concerning the trial court adding the indication that judges are chosen between those specialised in economic and financial matters. $^{23}$

The provisions contained in the Corpus Juris also stipulate a list of rules guaranteeing defence rights, e. g. the right to silence ${ }^{24}$, protection from self incrimination, presumption of innocence ${ }^{25}$, assistance of a lawyer ${ }^{26}$ and the ultimate use of pretrial custody ${ }^{27}$. Moreover, as a corollary to European territoriality ${ }^{28}$, the accused should benefit from the prohibition of ne bis in idem.

In order to provide for a greater protection of fundamental rights, the Corpus Juris foresees the establishment of a judge of freedoms designated by each Member State. ${ }^{29}$ His/her warrant is necessary in all cases when a measure seriously affects a person's rights ${ }^{30}$, e. g. gives permission for search and seizure ${ }^{31}$, authorises a demand

${ }^{19}$ M. Delmas-Marty/J. A. E. Vervaele (eds.), ibid., op. cit. p. 188.

${ }^{20}$ Art. 18.4, Appendix III, op. cit.

${ }^{21}$ Art. 24.1 a), Appendix III, op. cit.

${ }_{22}$ M. Delmas-Marty/J. A. E. Vervaele (eds.), ibid., op. cit. p. 187.

${ }^{23}$ Art. 26.1, Appendix III, op. cit.

${ }^{24}$ Art. 20.3(a) and p. 200, Appendix III, op. cit.

${ }^{25}$ Art. 31.1, Appendix III, op. cit.

${ }^{26}$ Art. 32.1, Appendix III, op. cit.

${ }^{27}$ Art. 25 quater.3, Appendix III, op. cit.

${ }^{28}$ M. Delmas-Marty/J. A. E. Vervaele (eds.), ibid., op. cit. p. 188.

${ }^{29}$ Art. $25^{\text {bis. } 1}$, Appendix III, op. cit.

${ }^{30}$ M. Delmas-Marty/J. A. E. Vervaele (eds.), ibid., op. cit. p. 187.

${ }^{31}$ Art. 20.3 (d), Appendix III, op. cit. 
to produce documentation and computer data ${ }^{32}$, grants European arrest warrant$\mathrm{s}^{33}$ and orders remanding the individual in custody ${ }^{34}$. S/ he also plays an important role by granting an extension to the time of the preparatory stage ${ }^{35}$ and in deciding upon the committal to trial ${ }^{36}$.

The adversariality of the criminal procedure is expressed in the right of the accused to have access to any evidence which is presented to the judge. ${ }^{37}$

Finally, the Corpus Juris provides for a certain harmonisation of the admissibility of evidence, giving rules for certain types of evidence such as: testimony, questioning of the accused, statements of the accused outside the interrogations, experts' opinion, pre-existing documents, etc. Nevertheless, the Member State's laws determine whether the evidence has been obtained legally.

Based on the above brief description, one may conclude that the EPP - and the Corpus Juris - represented a model strongly based on supranational harmonised provisions to be complemented in certain scenarios by mutual recognition (like the EAW or the enforcement of judgements, for example). The Corpus Juris avoided elaborating detailed rules of the procedure applicable to the activities of the EPP and the admissibility of evidence. Instead, the Corpus Juris aimed at opening the debate on those legitimate aims that may be protected beyond the traditional concept of the nation state and developing a supranational enforcement model to that purpose.

\section{The Green Paper of the Commission}

Although the Corpus Juris received substantial support from certain actors at EU level, the proposal of the Commission tabled during the negotiations of the Nice Treaty to include a provision on the establishment of the EPP into the Treaty, failed. Instead, Eurojust was given a legal basis in the Treaty. ${ }^{38}$ The Commission, including OLAF and the European Parliament, remained convinced, however, that Eurojust and the horizontal cooperation model it represented - was not sufficient to ensure the protection of the financial interests of the EU. The Commission, therefore, put forward a Green Paper in 2001, on the criminal law protection of the financial interests of the Community and the establishment of a European Public Prosecutor. $^{39}$

\footnotetext{
32 Art. $20 \S 3$ (b), Appendix III, op. cit.

${ }^{33}$ Art. $25^{\text {ter. }}$, Appendix III, op. cit.

${ }^{34}$ Art. 25quater.1, Appendix III, op. cit.

${ }_{35}$ Art. 25.2, Appendix III, op. cit.

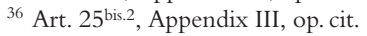

37 'Principle of proceedings which are 'contradictoire': 'The principle of proceedings which are 'contradictoire' implies, within respect for equality of arms as defined by the European Court of Human Rights, that the parties can have access to any evidence or observation presented to the judge (even when this is presented by a party to the proceedings, or by an independent prosecutor), with a view to influencing and discussing the judge's decision.', $M$. Delmas-Marty/J. A. E. Vervaele (eds.), ibid., op. cit. p. 188.

${ }_{38}$ Art. 31 of the Treaty on European Union, Consolidated Version, OJ No. C 325, 24 ${ }^{\text {th }}$ December, 2002, p. 1.

${ }^{39}$ Green Paper on criminal-law protection of the financial interests of the Community and the establishment of a European Prosecutor, COM (2001) 715 final, 11 ${ }^{\text {th }}$ December, 2001.
} 
The aim of the Green Paper was to generate wide public debate on the EPP. It drew up a new model of the EPP; on several points, however, it proposed alternative solutions or phrased questions rather than formulating ready-made suggestions. Compared to the Corpus Juris, the Green Paper [GP] put forward a more modest proposal of supranational law enforcement, also paying tribute to the policy development expressed in the Tampere Programme, adopted in the interim, which clearly prioritised mutual recognition over further harmonisation of the criminal laws of the Member States. ${ }^{40}$ Accordingly, the GP was not aimed at a wide scale harmonisation of national criminal procedures, but was reliant on mutual recognition instead. ${ }^{41}$ Surprisingly, it said little on the protection of fundamental rights (the GP refers to the European Convention on Human Rights without formulating the provisions itself), the admissibility of evidence and the role of the judge of freedoms. The Commission clearly aimed at avoiding issues that could have evoked strong opposition in the Member States. According to the general approach advocated in the GP, Community law should establish only the minimum rules necessary for the functioning of the EPP and leave as much freedom as possible to the Member States for the implementation. ${ }^{42}$

The GP did not alter the overall architecture of the EPP which continued to be based on a division of tasks between a chief EPP, who would centralise investigation and prosecution of cases falling under his/her competence, and Deputy Prosecutors, who would be integrated into the national justice systems and who would actually commit cases for trial. For obvious reasons of consistency and unity, the EPP would be - as in the Corpus Juris - hierarchical.

Similarly to the Corpus Juris, the GP envisaged an EPP that searches for evidence in favour of and against the suspect ${ }^{43}$, and which works on the basis of the principle of mandatory prosecution albeit with a margin of discretion in respect of cases of "minor impact on the Community's financial interests" 44 . The prosecutorial discretion exercised by the EPP must be met by rules of accountability. The GP therefore stipulates that the decision concerning the committal to trial or that of the dropping of the case is subject to judicial review exercised by the Member State's courts designated for this purpose according to national rules. ${ }^{45}$ Moreover, the GP maintained the concept of the Corpus Juris of adversarial proceedings and granted parties and their lawyers access to the EPP's file. ${ }^{46}$

Although according to the GP, the EPP would exercise its powers in "a common investigation and prosecution area"47 - meaning that its acts would have the same value and effect throughout the territory of the Member States -, the majority of investigation and prosecution measures were conceived on the basis of mutual

\footnotetext{
${ }^{40}$ Presidency Conclusions, Tampere European Council, $15^{\text {th }}$ and $16^{\text {th }}$ October, 1999 , points $33-37$.

${ }^{41}$ Green Paper, op. cit., p. 42.

42 Green Paper, op. cit., p. 20.

${ }^{43}$ Green Paper, op. cit., p. 44.

${ }^{44}$ Green Paper, op. cit., p. 45-46.

45 Green Paper, op. cit., p. 62-63.

${ }^{46}$ Green Paper, op. cit., p. 44.

${ }^{47}$ Green Paper, op. cit., p. 23.
} 
recognition. The GP did not list the investigation measures that should be available to the EPP. It only stated that the EPP should have access to the entire range of investigation measures available within the national systems to combat financial crimes, such as to gather or seize useful information, hear witnesses and question suspects, subpoena suspects, conduct searches and seizures, freeze assets, order telephone taps or other high tech communication interceptions and use special investigation techniques (covert investigations, controlled deliveries).

Instead of an exhaustive list, the GP established three categories of investigation measures. The first category, called "Community investigation measures", included measures that do not involve coercive powers - e. g. collecting and seizing information or hearing witnesses as well as questioning of the accused with his consent ${ }^{48}-$ and which should be regulated by EU law. The second and third categories both contained measures implying the use of coercive powers and require a court warrant. The second category included coercive investigation measures with the exemption of measures restricting the liberty of the accused (with the latter falling into the third category). These measures should take the form of orders made by the EPP and should continue to be regulated by national law. In lack of applicable supranational rules in the second category, these measures should be subject to mutual recognition. Accordingly, the applicable national law at the warrant stage would be that of the Member State of the forum, and at the execution stage, it would be that of the Member State of the place of execution of the investigation measure, if the latter is a different Member State. In the concept of the GP, the warrant and the execution should be mutually recognised and evidence should be mutually admissible between the Member States. The third category of investigation measures proposed by the GP is not a real category, as such. The third category only mentioned the European arrest warrant which - at the time of drawing up the GP - was only a Commission proposal. ${ }^{49}$

The dominance of national laws not only applied to coercive investigation measures, but also to the admissibility of evidence. Consequently, the GP did not provide for any harmonisation of the rules on the admissibility of evidence. Instead, in line with the Tampere Programme, ${ }^{50}$ it stipulated the mutual admissibility of evidence meaning that the trial court must admit any evidence lawfully obtained in accordance with the law of another Member State. Issues of legality and exclusion of evidence would be examined according to the rules of the Member State where the evidence was obtained. ${ }^{51}$

Although the GP rendered much of the functioning of the EPP to be based on mutual recognition, the development of procedural safeguards was omitted. Instead of formulating provisions concerning the protection of fundamental rights and, in

\footnotetext{
${ }^{48}$ Green Paper, op. cit., p. 51.

${ }^{49}$ Proposal for a Council Framework Decision on the European arrest warrant and the surrender procedures between the Member States (presented by the Commission), COM(2001) 522 final/2, 25 $5^{\text {th }}$ September, 2001.

${ }^{50}$ „Evidence lawfully gathered by one Member State's authorities should be admissible before the courts of other Member States", Presidency Conclusions, Tampere..., op. cit., pt. 36.

${ }^{51}$ Green Paper, op. cit., p. 58-59.
} 
particular, defence rights, the GP simply made reference to the ECHR instead ${ }^{52}$. It only explicitly mentioned the principle of the presumption of innocence and the ne bis in idem rule, albeit without going into details. ${ }^{53}$

Another striking difference between the Corpus Juris and the GP is the brief treatment of the judge of freedoms and judicial review. While the Corpus Juris not only provided for a judge of freedoms but also described its competences at large, the GP was more tacit on this issue. Taking into account different traditions among the Member States, according to the GP, acts authorized by the judge of freedoms shall be submitted to judicial review if the national law allows it. The Commission suggested harmonisation only in order to establish the rule that applications for review do not have suspensory effect. ${ }^{54}$ Nevertheless, the Commission was in favour of establishing such a body in order to review the coercive measure applied by the EPP and to evaluate the decision of the EPP to commit the case to trial. The GP left, however, the regulation of the status and procedure of such a judge (or tribunal) entirely to the Member States. ${ }^{55}$

It follows from the summary above that the GP considerably modified the original concept of the EPP by substituting many supranational elements through mutual recognition. Instead of the partial establishment of supranational criminal law and enforcement as ambitiously formulated in the Corpus Juris, the GP reflected on the policy development expressed in the Tampere Programme and took into account the Members States' 'fear of further EU criminal law harmonisation'. The Commission was very clear that it did not want "to enact a full body of common European legislation governing investigations". "As a result, the model drawn up in the GP suffers from the inherent contradiction of wanting to create a "common investigation and prosecution area", without however, adopting a common set of supranational rules and equivalent standards for this area.

The half-hearted solution of the GP is evident in the neglected status of defence rights, as well as the open-ended proposals on judicial review. The wish to avoid the harmonisation of national criminal procedures ended in the somewhat paradoxical proposal that the more coercive an investigation measure is, the narrower the scope for applicable supranational standards and the greater the importance of purely domestic rules. Such a proposal leads inevitably to forum shopping by the EPP.

In 2002, the Commission conducted a wide, public consultation on the GP and published its results in a follow-up report. ${ }^{57}$ The consultation procedure revealed some of the shortcomings of the GP, inter alia, the lack of specific rules to safeguard fundamental rights for the EPP's investigation, the possible forum shopping by the EPP in choosing the judge of freedoms to be approached for authorisation of

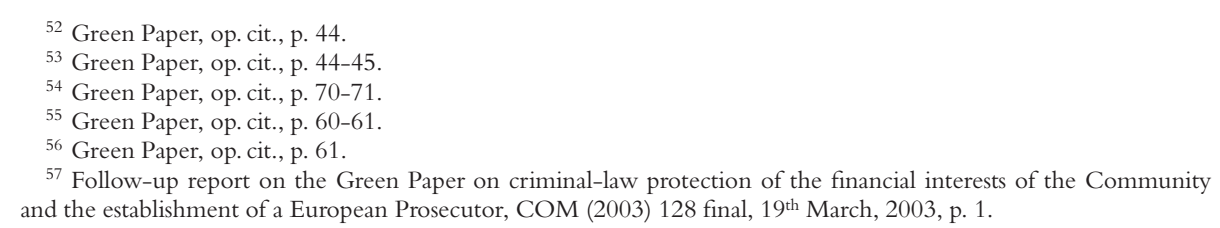


measures of investigation, the "levelling down" of the procedural guarantees by the proposed mutual admissibility of evidence, etc. Being conscious both of the Member States' conditional support for the $\mathrm{EPP}^{58}$ and the weaknesses of the GP, the Commission concluded that the GP and the consultation procedure were successful. The EPP became part of the Union's political agenda and the GP paved the way for the insertion of the EPP in the Constitutional Treaty. ${ }^{59}$

\section{The Constitutional Treaty and Art. 86 TFEU}

Indeed, Art. III-274 of the Constitutional Treaty ${ }^{60}$ contained a provision on the European Public Prosecutor's Office [EPPO] which was then copied into Art. 86 TFEU and extended by a provision on the possibility of introducing the EPPO through enhanced cooperation among at least nine Member States. According to Art. 86 TFEU:

'1. In order to combat crimes affecting the financial interests of the Union, the Council, by means of regulations adopted in accordance with a special legislative procedure, may establish a European Public Prosecutor's Office from Eurojust. The Council shall act unanimously after obtaining the consent of the European Parliament. In the absence of unanimity in the Council, a group of at least nine Member States may request that the draft regulation be referred to the European Council. [...]

2. The European Public Prosecutor's Office shall be responsible for investigating, prosecuting and bringing to judgment, where appropriate in liaison with Europol, the perpetrators of, and accomplices in, offences against the Union's financial interests, as determined by the regulation provided for in paragraph 1. It shall exercise the functions of prosecutor in the competent courts of the Member States in relation to such offences.

3. The regulations referred to in paragraph 1 shall determine the general rules applicable to the European Public Prosecutor's Office, the conditions governing the performance of its functions, the rules of procedure applicable to its activities, as well as those governing the admissibility of evidence, and the rules applicable to the judicial review of procedural measures taken by it in the performance of its functions.

4. The European Council may, at the same time or subsequently, adopt a decision amending paragraph 1 in order to extend the powers of the European Public Prosecutor's Office to include serious crime having a cross-border dimension and amending accordingly paragraph 2 as regards the perpetrators of, and accomplices

\footnotetext{
58 According to the 2003 follow-up report on the Green Paper, the Member States could be divided into three categories: those who support the principle of establishing an EPP, those who are simply sceptical about the usefulness or feasibility of the idea and those who reject the project out of hand. Follow-up report on the Green Paper, op. cit., p. 6. This would seemingly continue to be a good reflection of the status quo. According to the lunch debate organized by the Spanish Presidency on 15th April, 2010, on "The European Public Prosecutor's Office in the European judicial area", Member States expressed the same attitudes.

59 Treaty establishing a Constitution for Europe, OJ No C 310, 16 December 2004, p. 1.

${ }^{60}$ Treaty establishing a Constitution for Europe, op. cit., p. 121.
} 
in, serious crimes affecting more than one Member State. The European Council shall act unanimously after obtaining the consent of the European Parliament and after consulting the Commission.'

Art. 86 TFEU sets only the minimum confines for the establishment of the future EPPO leaving much leeway for implementation to the Member States. What is clear is that the EPPO will be a supranational body within the Area of Freedom, Security and Justice and must, therefore, comply with the objectives of that area, namely "respect for fundamental rights and the different legal systems and traditions of the Member States". 61 Furthermore, Art. 86 TFEU sets certain requirements on two key issues of the EPPO's implementation. According to Art. 86 TFEU, the EPPO shall be established from Eurojust and not from OLAF. Secondly, Art. 86 TFEU leaves no doubt that the adjudication does not belong at the European level but remains within the competence of the Member States. Within these confines, there remain, however, many questions related to the future functioning of the EPPO. ${ }^{62}$

Without doubt, a key issue will be the definition of the material scope of the EPPO. According to Art. 86 (1) TFEU, the EPPO will be established "in order to combat crimes affecting the financial interests of the Union". According to Art. 86 (4) TFEU, however, the competence of the EPPO can be extended - by unanimous decision of the Council - "to include serious crimes having a cross-border dimension". The interpretation of Art. 86(1) and (4) TFEU raises many legal and technical questions that will influence the room for manoeuvre available to the Member States. First, which crimes fall within the ambit of crimes "affecting" the financial interests of the Union"? Only those that actually or potentially harm the financial interests of the EU, like fraud, for example? Or also other behaviour that indirectly affects the allocation and management of EU funds both at the European and national level, which are, however, much more linked to the proper, impartial and transparent functioning of the EU's public administration, like, e.g. corruption? ${ }^{63}$ Furthermore, is it sound practice to limit the competence of the EPPO to the protection of the financial interests of the EU, a phenomenon which only indirectly

\footnotetext{
${ }^{61}$ Art. 67 of the Treaty on the Functioning of the European Union, OJ No C 83, 30th March, 2010, p. 47.

${ }^{62}$ Initial reactions were discussed at the conference "Quelles perspectives pour un ministère public européen: Protéger les intérêts financiers et fondamentaux de l'Union" organized by the Cour de Cassation on $11^{\text {th }}-12^{\text {th }}$ February, 2010, (publication by Dalloz, Paris 2010) and the information session organised by Eurojust on $28^{\text {th }}$ April, 2010. Issues discussed included, inter alia, the development of the EPPO in compliance with the Area of Freedom, Security and Justice, effects of a possible enhanced cooperation, the meaning of the establishment of the EPPO "from Eurojust", the EPPO's capacity for investigation and role of Europol and OLAF, relations between the EPPO and national authorities, the meaning of "crimes affecting the financial interests of the EU", powers of investigation of the EPPO and harmonisation of specific rules of procedure. It is astonishing that Art. 86 TFEU is silent on the judge of freedoms. See critics on the neglected status of the judge of freedoms during the 2002 public consultation procedure on the EPP in Follow-up report on the Green Paper on criminal-law protection of the financial interests of the Community and the establishment of a European Prosecutor, COM (2003) 128 final, $19^{\text {th }}$ March, 2003.

${ }^{63}$ In that context it is certainly instructive to refer to the Preamble of the First Protocol to the PIF Convention, which explicitly stated that European financial interests can be affected not only by fraud, but equally by other criminal conduct such as criminal behaviour of European or national officials when managing EU funds, for example. Protocol drawn up on the basis of Article K. 3 of the Treaty on European Union to the Convention on the protection of the European Communities' financial interests. OJ C 313, 23-10-1996, p. 2.
} 
touches the lives of EU citizens compared to general cross-border criminality, for example? What is the exact relationship of Art. 86 (1) and (4) TFEU? Is it possible to establish the EPPO through enhanced cooperation of at least 9 Member States with an enlarged competence to prosecute serious cross-border crime? ${ }^{64}$ And most importantly, does the creation of the EPPO require the harmonised definition of offences falling in the competence of the EPPO?

For setting up the EPPO one may expect lengthy negotiations not only on substantive criminal law, but according to Art. 86 (3) Member States will also have to decide upon the general rules applicable to the EPPO, the conditions governing the performance of its functions, the rules of procedure applicable to its activities (investigation, prosecution, bringing to judgment), the rules of procedure governing the admissibility of evidence, and the rules applicable to the judicial review of procedural measures taken by the EPPO in the performance of its functions. The procedural aspects of the EPPO are inextricably connected to the substantive law choices taken in the first place and vice versa.

Despite the open formulation of Art. 86 TFEU, the adoption of the Lisbon Treaty created new momentum to discuss the details of establishing the EPPO. In preparing for the Spanish Presidency of the EU Council, the Spanish General Prosecutor's Office and the Centre for Legal Studies set up a group of experts to reflect on the EPPO. According to their proposal, ${ }^{65}$ the EPPO should be based on a hierarchical structure of a limited chief EPP, who would centralise investigation and prosecution of cases falling under its competence, and Deputy Prosecutors, who would be integrated into the national justice systems ("double hat") and who could be national members of Eurojust. Though the EPPO should work on the principle of mandatory prosecution, it should enjoy discretion in respect of minor cases. With a view to the rules applicable to the investigations of the EPPO, the Spanish proposal foresees that the EPPO should be able to order coercive measures without judicial warrant including, for example, mandatory summoning of witnesses, requests for reports, documents, seizures, controlled delivery authorizations. However, measures restricting personal liberty should be authorized by a national judge of freedoms.

Besides the "Spanish model", during the strategic seminars 66 organised by Eurojust on its future, also a fourth model based on Art. 85 seems to crystallise and form the current debates on the creation of the EPPO. According to Art. 85 (1) a) and c) TFEU the future regulation dealing with the powers of Eurojust "may include the

\footnotetext{
${ }^{64}$ It is hard to imagine that the Council would agree to extend the material scope of the EPPO by unanimous decision to cover cross-border crime, on the one hand, and disagree at the same time on the establishment of the EPPO per se, on the other. Therefore, in the author's point of view, the EPPO's competence cannot be extended on the basis of Art. 86(4) TFEU if the EPPO is set up by enhanced cooperation.

${ }^{65}$ J.A. Espina Ramos/I. Vicente Carbajosa, The Future European Public Prosecutor's Office, Boletín del Estado, 2009.

${ }^{66}$ In 2010, Eurojust organized an information session and a strategic seminar. The information session was held in The Hague on $28^{\text {th }}$ April, 2010, and resulted in an informal document containing the conclusions. The strategic seminar was organised jointly with the Belgian Presidency on $20^{\text {th }}-22^{\text {nd }}$ September, 2010 in Brugge, Doc. 17625/10, REV 1, Brussels, $9^{\text {th }}$ December, 2010.
} 
power to initiate investigations [...] particularly, [...] relating to offences against the financial interests of the Union." At the same time, Article 85 (2) stipulates that "formal acts of judicial procedure shall be carried out by the competent national officials". The meaning of Art. 85 (1) a) read together with Art. 85 (2) is far from clear: does it mean that Eurojust - via its national members? - can order the commencement of investigations by the national authorities in the Member States? Or rather that the national members of Eurojust - as competent national officials can commence investigations to be followed up by the national authorities in the Member States? The extent of binding powers attributed to Eurojust in the future depends not only on the interpretation of "to initiate", but also on the scope of meaning of "investigations". According to the proponents of the "Eurojust Plus" model, the national members of Eurojust should receive binding powers based on Art. 85 TFEU to order the start of investigations by their national authorities and to issue decisions to resolve conflicts of jurisdiction. Although these new powers of Eurojust would be less than that which an EPPO may theoretically have, they would nevertheless be sufficient to guarantee the follow-up of OLAF's administrative investigations. The "Eurojust Plus" model thereby diminishes the practical need for the EPPO. One may also consider the "Eurojust Plus" model as an 'overkill' of the EPPO.

At first glance, it may seem convincing that Member States would be more inclined to support the progressive increase of the powers of Eurojust based on Art. 85 TFEU rather than establish a truly supranational investigation and prosecution body, the EPPO, under Art. 86 TFEU. One should, however, not forget that Art. 85 and 86 TFEU fall under different legislative procedures. Art. 85 TFEU refers to the adoption of a regulation in accordance with the ordinary legislative procedure ${ }^{67}$, whereas Art. 86 TFEU speaks about the adoption of a regulation in accordance with a special legislative procedure ${ }^{68}$. It is therefore the will of the Member States - as expressed in the Treaty - to require a higher threshold for the setting up of the EPPO than for the reform of Eurojust. Implementing - even limited - supranational investigation powers through the backdoor of Art. 85 TFEU circumvents the will of the Member States and is likely to be met with fierce resistance by the constitutional courts in some Member States.

\section{Policy, institutional and legislative developments in the Area of Free- dom, Security and Justice}

As was pointed out earlier, the EPPO will be a supranational body within the Area of Freedom, Security and Justice [AFSJ] and must, therefore, take into account the policy, legislative and institutional developments shaping that area. All of these developments were marked during the last decade by the common trend that the

\footnotetext{
${ }^{67}$ Art. 289 and 294 of the Treaty on the Functioning of the European Union, OJ No C 83, 30 $0^{\text {th }}$ March, 2010, p. $172-175$.

${ }^{68}$ Art. 293 of the Treaty on the Functioning of the European Union, OJ No C 83, 30 th March, 2010, p. 173.
} 
idea of the Corpus Juris was too radical for the Member States to 'swallow' and, therefore, alternative schemes had been developed in order to improve the existing legal framework, i. e. international cooperation in criminal matters.

\section{Policy developments}

Central to EU action in Justice and Home Affairs has been the adoption of three, detailed five-year legislative and policy programmes: the Tampere Programme ${ }^{69}$, the Hague Programme ${ }^{70}$ and the recent Stockholm Programme ${ }^{71}$. These programmes contain an extensive list of long term and specific objectives to develop the AFSJ. They are accompanied with actions plans ${ }^{72}$ and in some cases by implementation programmes translating the political objectives into concrete target setting by proposing a series of legislative measures also indicating the envisaged date for their adoption. As a result of these programmes, an impressive number of EU legislative acts were adopted rendering the dynamism of the criminal justice field comparable to that of the internal market of the 80 s.

The first justice programme was the 1999 Tampere Programme. The EU Council wanted to give political impetus to the development of the Union objective of creating an "area of freedom, security and justice" by adopting the Tampere Programme. The most important innovation of the Tampere Programme was to endorse that the principle of mutual recognition "should become the cornerstone of judicial cooperation" in criminal matters. ${ }^{73}$ In the proposed system of mutual recognition, the judicial authorities of one Member State recognise and execute the decisions of judicial authorities of other Member States, with a minimum of formality and on the basis of mutual trust. In other words, the decision of the issuing state takes effect as such within the legal system of the executing state. The principle of mutual recognition constitutes, therefore, a developed form of cooperation mechanisms as it principally provides for the execution of foreign decisions, though such execution is not automatic.

Viewed from the historical perspective, the introduction of the principle of mutual recognition to the criminal law field was largely motivated by the Members States' fear of further EU criminal law harmonisation. In the late 90s, such fear emanated from ambitious proposals such as the Corpus Juris that advocated the partial establishment of supranational criminal law and enforcement. ${ }^{74}$ The appeal of mutual recognition relied precisely on the idea that it addressed the need for more effective cooperation in criminal matters in the EU without obliging the

\footnotetext{
${ }^{69}$ Presidency Conclusions, Tampere..., op. cit.

${ }^{70}$ Brussels European Council, $4^{\text {th }}$ and $5^{\text {th }}$ November, 2004, Presidency Conclusions, The Hague Programme, OJ No C53, $3^{\text {rd }}$ March, 2005, p. 1.

${ }^{71}$ Communication from the Commission to the European Parliament and the Council, The European Economic and Social Committee and the Committee of the Regions. COM (2010) 171 final, 20 th April, 2010, p. 1.

72 Council and Commission Action Plan implementing the Hague Programme on strengthening freedom, security and justice in the European Union, OJ C 198, $12^{\text {th }}$ August, 2005, p. 1. Action Plan Implementing the Stockholm Programme, COM (2010) 171 final, $20^{\text {th }}$ April, 2010.

${ }^{73}$ Tampere European Summit, op. cit., $\$ 33$ et seq.

${ }^{74}$ M. Delmas-Marty/J. Vervaele (eds.), The implementation of the Corpus Juris in the Member States, op. cit.
} 
Member States to adopt harmonised criminal law provisions. Advocating mutual recognition prioritized cooperation between jurisdictions over creating a single jurisdiction. Cooperation based on mutual recognition does not require uniformity of laws and procedures.

For endorsing mutual recognition, the Council developed a detailed implementation programme which specified the measures to be adopted on the basis of the mutual recognition principle. ${ }^{75}$ The first instrument applying the mutual recognition principle in the criminal law field was the 2002 Framework Decision on the European Arrest Warrant. ${ }^{76}$ This was followed by a series of mutual recognition instruments covering nearly all stages of the criminal process.

By promoting mutual recognition, the Tampere Programme clearly opted for improving traditional mechanisms of horizontal cooperation instead of establishing vertical cooperation. This decision is a fundamental choice and it has been characteristic in the developments of the last decade. ${ }^{77}$

Compared to the ambitions of the Tampere Programme, the 2005 Hague Programme was less coherent ${ }^{78}$ and was more driven by a security agenda. It was, however, more sober in the sense that it placed strong emphasis on consolidating the existing legal instruments instead of adopting new ones. The Hague Programme was negotiated in the aftermath of the terrorist attacks in New York and Madrid and consequently devoted much consideration to aspects of security, the boosting of operational action, the exchange of personal data for police purposes and the fight against terrorism. In the criminal justice field, the Hague Programme set the further improvement of judicial cooperation as an objective by reducing legal obstacles and strengthening the coordination of investigations. ${ }^{79}$ In order to do so, it proposed the adoption of a number of measures to implement the principle of mutual recognition, such as measures on gathering and admissibility of evidence, conflicts of jurisdiction and the ne bis in idem principle, the execution of final sentences of imprisonment and other (alternative) sanctions as well as equivalent standards for at least certain - procedural safeguards ${ }^{80}$.

The choice of the Tampere and Hague Programmes to develop avenues of more efficient horizontal cooperation was not only motivated by the Member States' rejection of vertical enforcement models. It was undoubtedly a result of the considerable institutional limitations of the ex-Third Pillar as well. ${ }^{81}$ Moving towards a single European criminal jurisdiction and harmonised rules of procedure

\footnotetext{
${ }^{75}$ Programme of measures to implement the principle of mutual recognition of decisions in criminal matters, OJ No. C $12,15^{\text {th }}$ January, 2001, p. 10.

${ }^{76}$ Council Framework Decision $2002 / 584 / \mathrm{JHA}$ of $13^{\text {th }}$ June, 2002 on the European arrest warrant and surrender procedures between Member States, OJ No. L 190, $18^{\text {th }}$ July, 2002, p. 1.

${ }^{77}$ It did not only mark the legislative development, but also the institutional one. Favouring new forms of horizontal cooperation was e.g. strengthened by the decision to establish Eurojust. Tampere European Summit, op. cit., recital 46.

${ }^{78}$ Large chapters were devoted to specific issues, like e. g. availability principle, fight against terrorism, etc.

79 The Council stressed the need to adopt e.g. new legislation on Eurojust. Presidency Conclusions, The Hague..., op. cit., pt. 3.3.3

${ }^{80}$ Presidency Conclusions, The Hague..., op. cit., pt. 3.3.1
} 
would have required granting additional powers to the EU in the criminal justice field. Political agreement to that end has been reached only in the Lisbon Treaty which abolished the pillar structure and brought criminal law under the community method. ${ }^{82}$

The Stockholm Programme was adopted on the basis of the ratified Lisbon Treaty and contains the long term and specific objectives of the EU to develop the AFSJ in the period 2010-2014. Apart from emphasising the need to preserve fundamental rights ${ }^{83}$, to make the European criminal justice system more "user friendly" and to extend mutual recognition to all types of judgments and decisions, the Stockholm Programme sets out the establishment of the EPPO as an objective. It makes it clear, however, that prior to the EPPO, the Member States need "to implement thoroughly" the Council Decision on Eurojust. ${ }^{84}$ In other words, new possibilities of vertical justice integration offered by the TFEU, can be considered only after an assessment and strengthening of horizontal cooperation (the implementation of the 2008 Eurojust Decision). The Stockholm Programme therefore gives the impression of a progressive approach, in which first the powers of Eurojust must be reinforced and the establishment of the EPPO can only follow it. Such a progressive approach is, however, much less clear from the recently adopted Action Plan of the Stockholm Programme, according to which the Commission is planning to table a new proposal until 2012 for a regulation providing Eurojust with powers to initiate investigations and making Eurojust's internal structure more efficient. In contrast, a communication on the establishment of the EPPO should be developed in 2013. It is unrealistic to assume that the Commission can come up with a communication on the EPPO in 2013 to be established "from Eurojust", while the 2012 proposal on the enlarged powers of Eurojust is probably still being negotiated. The political message of the closely timed planning of the reform of Eurojust and the reflection on the EPPO in the Action Plan is unclear. ${ }^{85}$ It may be interpreted that in order to comply with the time schedule of the Action Plan, the Commission will start working parallel - and not progressively! - on the reform of Eurojust and the creation of the EPPO. Such parallel work may imply a loose link between Eurojust and the future EPPO. The Action Plan may also be interpreted, however, to the contrary. Since communications are legislative targets that the Commission

\footnotetext{
${ }^{81}$ See rejection of the Framework Decision on certain procedural rights in criminal proceedings throughout the European Union with a reference to a lack of Treaty basis. V. Mitsilegas, The third wave of third pillar law: which direction for EU criminal justice?, p. 546.

82 Title $\mathrm{V}$ of the TFEU.

${ }^{83}$ Action Plan Implementing the Stockholm Programme prospects a green paper on procedural safeguards to be issued until 2014. Action Plan Implementing the Stockholm Programme, COM (2010) 171 final, 20 $0^{\text {th }}$ April, 2010, p. 14.

${ }^{84}$ Communication from the Commission to the European Parliament and the Council, The European Economic and Social Committee and the Committee of the Regions. COM (2010) 171 final, $20^{\text {th }}$ April, 2010, p. 2.

${ }^{85}$ Initial reactions were discussed at the conference "Quelles perspectives pour un ministère public européen: Protéger les intérêts financiers et fondamentaux de l'Union" organized by the Cour de Cassation on $11^{\text {th }}-12^{\text {th }}$ February, 2010, (publication by Dalloz, Paris 2010) and at the seminar organised by Eurojust on $20^{\text {th }}-22^{\text {nd }}$ September, 2010. Conclusions of the Strategic Seminar organized by Eurojust and the Belgian Presidency on "Eurojust and the Lisbon Treaty: Towards more effective action", Doc. 17625/10, REV 1, Brussels, $9^{\text {th }}$ December, 2010, p. 22.
} 
need not fulfil, such short timing of the Eurojust reform and the planning of the EPPO may mean that the Commission clearly accords political priority to the reform of Eurojust and attaches must less importance to the EPPO. Accordingly, the communication on the EPPO scheduled for 2013 may not be fulfilled.

It is interesting to note that the Action Plan of the Stockholm Programme is a "Commission Action Plan" which was adopted without the involvement of the Council. ${ }^{86}$ The Council, being disappointed with the Action Plan, in particular with the parts dealing with Eurojust and the EPPO, issued a set of conclusions distancing itself from the Action Plan. ${ }^{87}$ The reaction of the Council to the Action Plan of the Stockholm Programme clearly signals the tensions within the EU institutions in interpreting the provisions of the Lisbon Treaty.

It is too early at this stage to speculate over the implementation of the Action Plan of the Stockholm Programme. The Commission's attitude remains to be seen. The contradictory message sent on the EPPO reveals once again the sensitivity of supranational criminal law enforcement bodies. This sensitivity does not only derive from the Member States' sovereignty constraints, but it is also fostered by the field of power dominated by existing EU agencies and bodies (see below under II.2.). ${ }^{88}$

\section{Institutional developments}

The institutional developments of the last decade represent a particularly sensitive aspect for the creation of the EPPO. The establishment of the EPPO will have repercussions for all existing EU actors in the criminal law field and will inevitably result in a new design of their status and functions. The debate on the EPPO is, therefore, loaded with arguments relating to possible new allocation of functions.

In this respect, three institutions deserve greater attention: Eurojust, OLAF and Europol. From its birth, Eurojust has been linked to the idea of the EPPO. The creation of Eurojust took place in a climate influenced by tensions between the Commission on the one hand, who advocated a largely harmonised model of EU criminal justice formulated in the Corpus Juris and supported the idea of a European Public Prosecutor, and reluctant Member States on the other hand, who promoted mutual recognition rather than harmonisation in the criminal law field. ${ }^{89}$ The Commission made a proposal to the 2000 Intergovernmental Conference with the aim to include a provision on the establishment of the $\mathrm{EPP}^{90}$ into the Nice Treaty.

\footnotetext{
${ }^{86}$ Previous action plans, e.g. the action plan of the Hague Programme, was issued by the Commission and the Council, jointly. Council and Commission Action Plan implementing the Hague Programme on strengthening freedom, security and justice in the European Union, OJ No C 198, 12 ${ }^{\text {th }}$ August 2005, p. 1.

${ }^{87}$ The Council pointed out that the "Stockholm Programme is the only guiding frame of reference for the political and operational agenda of the European Union in the Area of Justice, Security and Freedom" and noted that "some of the actions proposed by the Commission are not in line with the Stockholm Programme and that others, being included in the Stockholm Programme, are not reflected in the Communication of the Commission." Council conclusions on the Commission Communication "Delivering an area of freedom, security and justice for Europe's citizens - Action Plan Implementing the Stockholm Programme", COM (2010) 171 final, $3^{\text {rd }}$ June, 2010.

${ }^{88}$ In December 2009, the College of Eurojust established a Task Force on the Future of Eurojust to reflect and continuously discuss the future developments of Eurojust and the establishment of the EPPO "from Eurojust". OLAF and DG Justice set up an informal joint working group on the Protection of the Financial Interests of the Union.

${ }^{89}$ V. Mitsilegas, EU Criminal Law, Hart Publishing, p. 188-189.
} 
The Commission's proposal failed, and Eurojust was given a legal basis in the Treaty. ${ }^{91}$ In contrast to the concept of the EPPO, Eurojust was conceived from the beginning as an intergovernmental body, composed of national members, one from each country. ${ }^{92}$ Eurojust did not obtain operational powers; it did not even become a requesting judicial authority. The main objectives of Eurojust were limited to stimulate and improve coordination between the competent authorities of the Member States, and to facilitate the execution of international judicial requests. ${ }^{93}$ Accordingly, the tasks of Eurojust embraced the requesting of a Member State to carry out an investigation or prosecution or to refrain from doing so, to coordinate the activities of the competent authorities of Member States' and to set up joint investigation teams. ${ }^{94}$ Eurojust was not granted mandatory powers to initiate investigations and prosecutions in the Member States. Furthermore, the powers of national members were defined by reference to the domestic law of their state of origin. This resulted in considerable discrepancies in the way each Member State defined these powers which again had serious repercussions on the efficiency of Eurojust. After an analysis of the functioning and future of Eurojust during the Austrian Presidency, ${ }^{95}$ a new Eurojust Decision was prepared which ought to rectify some of the problems. According to Art. 9 of the new Eurojust Decision, the national members of Eurojust have equivalent powers to exchange information and can issue requests for and decisions on judicial cooperation. This latter power may not be granted, however, if it is contrary to domestic constitutional law. In other words, the new Eurojust Decision refrained from introducing changes with regard to the mandatory character of Eurojust's request towards the national authorities to initiate investigations and prosecutions and towards mandatory decisions on jurisdiction. These are certainly crucial aspects in a future reform of Eurojust based on Art. 85 TFEU.

Regardless of the improved status and powers of the members of Eurojust, Eurojust still represents horizontal integration. With a view to the Lisbon Treaty and the creation of the EPPO "from Eurojust", reflection has already started on the future role of this body. We may certainly envisage different scenarios. One may think of the EPPO as a distinct body from Eurojust, which may, however, profit from the infrastructure of Eurojust. A much more integrated approach may be also envisaged, where Eurojust evolves through the reform based on Art. 85 TFEU into an embryo of the EPPO. In order to depart from this more integrated approach,

\footnotetext{
${ }^{90}$ Communication from the Commission. The criminal protection of the Community's financial interests: a European Prosecutor. Additional Commission contribution to the Intergovernmental Conference on institutional reforms, $\operatorname{COM}(2000) 608$ final, $29^{\text {th }}$ September, 2000.

${ }^{91}$ Art. 31 of the Treaty on European Union, Consolidated Version, OJ No. C 325, $24^{\text {th }}$ December, 2002.

${ }^{92}$ Art. 2. of the Council Decision 2002/187/JHA of $28^{\text {th }}$ February, 2002 setting up Eurojust with a view to reinforcing the fight against serious crime. OJ No. L 63, $6^{\text {th }}$ March, 2002, p. 1.

${ }^{93}$ Art. 3. of the Council Decision setting up Eurojust ..., op. cit.

${ }^{94}$ Art. 6. of the Council Decision setting up Eurojust ..., op. cit.

${ }^{95}$ Report of the seminar: "A Seminar with 2020 Vision: The Future of Eurojust and the European Judicial Network", Vienna, $25^{\text {th }}-26^{\text {th }}$ September, 2006, Council doc. 14123/06.
} 
certain prior reforms must be implemented in respect of the powers and internal organisation of Eurojust. $^{96}$

Besides Eurojust, Art. 86 TFEU mentions a second actor: Europol. The establishment of Europol dates back to the beginning of the $90 \mathrm{~s}^{97}$ when the initiative of setting up a European "FBI" was launched. The cumbersome negotiation of the Europol Convention was completed in 1995, but it took until 1 ${ }^{\text {st }}$ October, 1998 to finalise the ratification process so that Europol became operational as of $1^{\text {st }}$ July, 1999. The basic task of Europol is to give support to Member States through the exchange of information for law enforcement purposes and by the analyses of available information in respect of offences within its remit. The original limitation of Europol's competence regarding organised crime $^{98}$ was gradually widened to cover money laundering ${ }^{99}$, terrorism and other serious crimes laid down in a list attached to the Convention. Europol is confined to provide assistance to criminal investigations led by the Member States and it did not receive genuine investigative powers. The concept of Europol as an information service tool was also maintained in the 2008 Europol Decision. Art. 88 TFEU may open the field for new reflections on the operational added value of Europol in the context of the AFSJ. A prerequisite for allocating Europol 'true' investigative powers is, however, to define the body in charge of controlling and directing Europol's work as well as to provide for judicial review. Taking into account the fact that the EPPO's future competence ("crimes affecting the financial interests of the Union") do not correspond to the current mandate of Europol, the EPPO cannot perform the task of controlling and directing the activities of Europol. The divergence in competence between the different EU law enforcement agencies will hinder the establishment of an integrated judicial structure, and will result in increased concerns in relation to the control of strong investigative powers at the European level.

Whereas Art. 86 TFEU refers explicitly to Eurojust and Europol, it is silent on OLAF, a circumstance that has already given rise to many speculations. The silence of the Treaty on OLAF does not change, however, the fact that OLAF has important and valuable experience concerning financial investigations, in particular concerning investigations within the institutions, organisations and bodies of the EU.

\footnotetext{
${ }^{96} \mathrm{~J}$. A. Vervaele, European Enforcement Agencies in the Area of Freedom, Security and Justice: the Eurojust European Public Prosecutor binomial, Proceedings of the 5th European Jursit Forum, Budapest 2009, pp. 117-138. It should be noted that a possible scenario could be to transform Eurojust into a "mini-EPPO" based on Art. 85 TFEU by granting Eurojust members the mandatory right to initiate investigations and prosecutions in the Member States for crimes affecting the financial interests of the EU. Such a "mini-EPPO" could overkill the debate on a fully fledged EPPO based on Art. 86 TFEU. There is a lot of speculation in assessing the chances of such a scenario which go beyond the scope of the present paper. In any case, this scenario may oversee the strong symbolic value the EPPO represents for developing the AFSJ.

${ }^{97}$ Initiative of Kohl at the Luxembourg European Council $28^{\text {th }}$ and $29^{\text {th }}$ June, 1991, Luxembourg European Council Conclusions, Bulletin 02. 07. 1991, PE 151.797.

${ }^{98}$ Art. 2 of the Convention based on Article K.3 of the Treaty on European Union, on the establishment of a European Police Office (Europol Convention), OJ No C 316, 27 th November, 1995, p. 2.

${ }_{99}$ Protocol drawn up on the basis of Article 43(1) of the Convention on the establishment of a European Police Office (Europol Convention) amending Article 2 and the Annex to that Convention, OJ No. C 358, $13^{\text {th }}$ December, 2000 , p. 1.
} 
OLAF was set up through the reform of UCLAF in $1999^{100}$ as a response to the crisis of the Santer Commission and to grave allegations about the illegal use of the Community funds in the Member States. OLAF's objectives are to combat fraud, corruption and "any other illegal activity adversely affecting the Community's financial interests" 101 by means of external and internal administrative investigations. The rules concerning OLAF's functioning and procedure are laid down in Regulation No $1073 / 1999^{102}$, granting the right to OLAF to start proceedings on its own initiative. ${ }^{103}$ The Community bodies and to some extent the Member States are obligated to transmit to OLAF any information regarding possible cases of illegal activities falling in the scope of OLAF's competence. ${ }^{104}$ The investigative powers of OLAF include, inter alia, the "right to immediate and unannounced access to any information held by the institutions, bodies, offices and agencies, and to their premises" $" 105$ as well as the right to inspect the accounts of these bodies, to request oral information of its members or to carry out on-the-spot inspections in the offices of economic operators concerned. Due to these investigative powers, OLAF is currently the only supranational law enforcement body equipped with operative tasks. OLAF became a powerful administrative investigative body, albeit with limited powers: both judicial coercive measures and administrative sanctioning are excluded. In contrast to Europol and Eurojust, however, owing to its operational capacities, OLAF does not depend on the willingness of Member States to feed cases and share information.

Both the operative tasks of OLAF and its status have provoked fierce debate ever since its existence. Regardless of the administrative nature of OLAF's investigations, the use of information and data forwarded by OLAF as evidence in domestic criminal proceedings led to concerns in the Member States both in terms of State sovereignty ${ }^{106}$ and defence rights. ${ }^{107}$ Another part of the criticism focused on the ambiguous status of OLAF: OLAF is an independent administrative organ on the one hand, and part of the Commission and its budget on the other hand. The Director of OLAF has the duty to regularly report not only to the European Parliament, the Council and the Court of Auditors but also to the Commission. ${ }^{108}$ Although OLAF's independence - crucial to its investigative powers - is reinforced by stipulating that the Director of OLAF may neither seek nor accept any instructions from governments of institutions in his/her investigative capacity and an

\footnotetext{
${ }^{100}$ Commission Decision 1999/352/EC, ECSC, Euratom of 28 th April, 1999, establishing the European Antifraud Office (OLAF), OJ No L136, 31st May, 1999, p. 20.

101 Art. 2 pt. 1 Commission Decision establishing OLAF, op. cit.

102 Regulation (EC) No 1073/1999 of the European Parliament and of the Council of $25^{\text {th }}$ May, 1999, concerning investigations conducted by the European Anti-Fraud Office (OLAF), OJ No L 136, 31 May 1999, p. 1.

103 Art. 5 of the Regulation concerning investigations conducted by OLAF, op. cit.

${ }^{104}$ Art. 7 of the Regulation concerning investigations conducted by OLAF, op. cit.

105 Art. 4 point 2 of the Regulation concerning investigations conducted by OLAF, op. cit.

106 V. Mitsilegas, EU Criminal Law, op. cit., p. 212.

107 Judgment of the Court of First Instance of 4 October 2006 - Tillack v Commission (Case T-193/04), OJ No C 251, $9^{\text {th }}$ October, 2004, and Judgment of the Court of First Instance of $8^{\text {th }}$ July, 2008 - Franchet and Byk $v$ Commission (Case T-48/05), OJ No C 209, $15^{\text {th }}$ August, 2008, p. 44.

108 Art. 12 of the Regulation concerning investigations conducted by OLAF, op. cit.
} 
independent Surveillance Committee monitors the activities of OLAF, OLAF remains a department of the Commission.

The Green Paper on the EPP has already made mention of the possibility of assigning judicial investigative powers to OLAF concerning the EU bodies and institutions. To transform OLAF into a kind of supranational police entrusted with internal investigations within the EU bodies and institutions would ultimately require removing it from the Commission, in addition to granting OLAF true and full independence. The ideas floated by Manuel Barroso on the occasion of the entry into force of the new Commission referring to OLAF becoming fully independent from the European Commission, point in that direction.

Future EU institutional developments in the criminal justice field undoubtedly pertain to highly interesting prospects opened up by the Lisbon Treaty. The debate on the possible future functions and roles of the existing institutions is strongly influenced by the possibility of setting up an EPPO. Conversely, concepts focusing on the EPPO must pay attention to the powers, institutional organisation and realistic aspirations of existing EU criminal justice bodies. It must be kept in mind that the future EPPO would not only need to be strongly embedded in the domestic judicial structure of the Member States, but would also need operational judicial authorities at the European level. ${ }^{109}$ This implies strong operational connections between the EPPO on the one hand, and Europol and OLAF on the other.

\section{Legislative developments}

Since Tampere, the principle of mutual recognition has been the motor of legislative development in EU criminal justice. So far, ten instruments based on mutual recognition have been adopted. ${ }^{110}$ These instruments encompass certain

\footnotetext{
${ }^{109}$ J. A. Vervaele, European Enforcement Agencies in the Area of Freedom, Security and Justice: the Eurojust European Public Prosecutor binomial, Proceedings of the $5^{\text {th }}$ European Jursit Forum, Budapest 2009, pp. 117-138.

${ }_{110}$ Council Framework Decision 2002/584/JHA of $13^{\text {th }}$ June, 2002 on the European arrest warrant and surrender procedures between Member States, OJ No. L 190, $18^{\text {th }}$ July, 2002, p. 1; Council Framework Decision 2003/577/ JHA of $22^{\text {nd }}$ July, 2003, on the execution in the European Union of orders freezing property or evidence, OJ No. L 196, $2^{\text {nd }}$ August, 2005, p. 45.; Council Framework Decision 2005/214/JAI of $24^{\text {th }}$ February, 2005, on the application of the principle of mutual recognition to financial penalties, OJ No. L 76, 22 ${ }^{\text {nd }}$ March, 2005, p. 16.; Council Framework Decision 2006/783/JHA of $6^{\text {th }}$ October, 2006, on the application of the principle of mutual recognition to confiscation orders, OJ No. L 328, 24 $4^{\text {th }}$ November, 2006, p. 59.; Framework Decision 2008/675/JHA of $24^{\text {th }}$ July, 2008, on taking account of convictions in the Member States of the European Union in the course of new criminal proceedings, OJ No. L 220, $15^{\text {th }}$ August, 2008, p. 32.; Framework Decision 2008/947/JHA of $27^{\text {th }}$ November, 2008 on the application of the principle of mutual recognition to judgments and probation decisions with a view to the supervision of probation measures and alternative sanctions, OJ No. L 337, 16 th $^{\text {th }}$ December, 2008, p. 102; Framework Decision $2008 / 909 / \mathrm{JHA}$ of $27^{\text {th }}$ November, 2008, on the application of the principle of mutual recognition to judgments in criminal matters imposing custodial sentences or measures involving deprivation of liberty, OJ No. L $3275^{\text {th }}$ December, 2008, p. 27; Framework Decision $2008 / 978 / J H A$ of $18^{\text {th }}$ December, 2008, on the European evidence warrant for the purpose of obtaining objects, documents and data for use in proceedings in criminal matters, OJ No. L 350, 30 th $^{\text {th }}$ December, 2008, p. 72; Council Framework Decision 2009/299/JHA of $26^{\text {th }}$ February, 2009, amending Framework Decisions 2002/584/JHA, 2005/214/JHA, 2006/783/JHA, 2008/909/JHA and 2008/947/ JHA, thereby enhancing the procedural rights of persons and fostering the application of the principle of mutual recognition to decisions rendered in the absence of the person concerned at the trial, OJ No. L 81, 27 th March, 2009, p. 24. Council Framework Decision 2009/829/JHA of 23 ${ }^{\text {rd }}$ October, 2009, on the application between Member States of the European Union of the principle of mutual recognition to decisions on supervision measures as an alternative to provisional detention, OJ No. L 294, $11^{\text {th }}$ November, 2009 p. 20.
} 
aspects of all stages of the criminal procedure: recognition and enforcement of pretrial orders, final judgements, sentencing, and post-sentencing follow-up judgements. They resulted in transforming the law on judicial cooperation in criminal matters from the traditional request principle to the mutual recognition of foreign judicial decisions. This development is, however, subject to powerful debates both within the academic community and among practitioners as well. The main objection voiced is one of principle, namely whether it is possible to apply the Community law concept of mutual recognition to the criminal law field. ${ }^{111}$ Other objections have pointed to the weaknesses experienced during the practical application of mutual recognition. ${ }^{112}$ The unsatisfactory level of implementation of several mutual recognition instruments certainly overshadows the success of the principle and is largely attributable to the fact that the application of mutual recognition in the criminal law field challenges the constitutional and criminal law traditions of the Member States. ${ }^{113}$ It provokes fierce debates related to the legitimacy and subsidiarity of EU action as demonstrated by decisions of the constitutional and supreme courts of certain Member States. ${ }^{114}$

Regardless of these reservations, mutual recognition has been confirmed at the political level in its key function as the motor of European penal law integration. Both the Lisbon Treaty ${ }^{115}$ and the Stockholm Programme grant mutual recognition a central role. In light of the previous shortcomings, maintaining mutual recognition for the future development of the EU criminal justice area requires revisiting its original concept.

According to the original concept, mutual recognition relied on three premises: first, that there is mutual trust between the judicial authorities of the Member States, which forms the basis of mutual recognition; secondly, that mutual recognition may function as an alternative to harmonisation of national criminal laws; and thirdly, that mutual recognition works automatically. In practice, all three premises turned out to have been misestimations, and must be corrected in the future.

This implies that instead of simply assuming mutual trust, measures for strengthening mutual trust must be put in place. Mutual trust is not only a precondition for an Area of Freedom, Security and Justice based on mutual recognition, but also a goal to be achieved. The need to establish mutual trust has been recognised at the

111 S. Peers, Mutual Recognition and Criminal Law in the European Union: Has the Council Got it Wrong?, Common Market Law Review 2004, nr 41, pp. 5-36.; F. Zeder, Europastrafrecht: Aktueller Stand, Österreichische Anwaltsblatt 2008, nr 6, p. 264.; A. Klip, European Criminal Law, Antwerp, Intersentia, 2009, pp. 351-352.

${ }^{112}$ See the repeated calls of the European Criminal Bar Association in respect of adopting common standards for procedural safeguards, press release available at www.ecba.org.

${ }^{113}$ V. Mitsilegas, The Constitutional Implications of Mutual Recognition in Criminal Matters in the EU, Common Market Law Review 2006, nr 43, pp. 1277-1311.

${ }^{114}$ German Constitutional Tribunal, 18 th July, 2005, Judgment 2 BVR 2236/04, [2006] 1 CMLR 16; Supreme Court of Cyprus, $7^{\text {th }}$ November, 2005, Judgment in case Attorney General of the Republic v Konstantinou, [2007] 3 CMLR 42; Constitutional Court of the Czech Republic, $3^{\text {rd }}$ May, 2006, Re Constitutionality of the Framework Decision on the European Arrest Warrant, [2007] 3 CMLR 24; Constitutional Tribunal of Poland, Judgment of 27th April, 2005, No. P 1/05; Constitutional Court of the Republic of Hungary, $8^{\text {th }}$ March, 2008, Decision No. 733/A/2007.

${ }^{115}$ Art. 82 TFEU according to which "[j]udicial cooperation in criminal matters in the Union shall be based on the principle of mutual recognition of judgements and judicial decisions." 
highest political level ${ }^{116}$ and led to proposing a variety of measures enhancing mutual trust. These measures consist of harmonising procedural safeguards, establishing evaluation mechanisms, securing better access to information, providing for training and networking of practitioners, and adopting best practices. All these efforts at the EU level to create mutual trust may, however, remain inconclusive without a certain level of harmonisation of criminal law. Contrary to the original understanding of mutual recognition, which implied that Member States are ready to recognise decisions of other Member States even if there are substantial differences between their legal systems, mutual recognition proved not to function in practice if these discrepancies are excessive. Adopting common standards - as promoted, for example, by the ill-fated proposal on procedural safeguards ${ }^{117}-$ is indispensable to improving mutual trust. Pre-existing harmonisation in criminal law renders mutual recognition easier; mutual recognition, however, may also be used as an argument for adopting harmonising measures. Conversely to the original British proposal, it is not practicable to agree only on the procedure of recognising national judicial decisions; it must be supplemented by agreement on the substantive rules on which such a decision was taken. ${ }^{118}$ Mutual recognition is, therefore, indispensably accompanied by harmonising measures. This is now acknowledged by the Lisbon Treaty that stipulates in Art. 67(3) TFEU that the Union will endeavour to ensure a high level of security through "the mutual recognition of judgments in criminal matters and, if necessary, through the approximation of criminal laws."

From the viewpoint of the functioning of the EPPO, both mutual recognition and harmonisation play a central role. As the concepts put forward by the Corpus Juris and the Green Paper on the EPPO demonstrate, finding the "right" balance between harmonised procedural rules and rules of procedure left to the domestic law of the Member States subject to mutual recognition will be one of the key issues in regulating the activities of the EPPO. The legal framework of the Lisbon Treaty provides the necessary legal basis to move on both in the direction of further harmonisation and mutual recognition in the field of criminal procedure. Drawing a balance between the two will be a task of the proposal for setting up the EPPO.

\section{Is mutual recognition a viable solution for the procedure of the EPPO?}

A central theme of the different models suggested for the creation of the EPPO is to define how far it is necessary to adopt a harmonised set of procedural rules for the functioning of the supranational EPPO, and to what extent it is possible to rely on mutual recognition.

\footnotetext{
${ }^{116}$ Presidency Conclusions, The Hague..., op. cit., p. 26.

${ }^{117}$ Proposal for a Council Framework Decision on certain procedural rights in criminal proceedings throughout the European Union, COM (2004) 328 final, $28^{\text {th }}$ April, 2004.

${ }^{118}$ H. Fuchs, Bemerkungen zur gegenseitigen Anerkennung justizieller Entscheidungen, Zeitschrift für die gesamte Strafrechtswissenschaft (ZStW) 2004, p. 269.; V. Mitsilegas, EU Criminal Law, Hart Publishing, Oxford, 2009, p. 124.
} 
In assessing this question, two factors must be taken into account: (i) the lessons of 10 years of practical experience with mutual recognition in the criminal law field and, (ii) the similarities and differences between the systems of investigation and prosecution in the Member States.

As far as the first aspect is concerned, one may speak about practical experiences with mutual recognition only in relation to the European arrest warrant because this is the only mutual recognition instrument in the criminal law field used in practice. All other mutual recognition instruments suffer from improper implementation and are hardly used by practitioners. It is evident that there is a gap between the theory and practice of mutual recognition. This gap is a result of the inconsistent approach of the Member States in creating the Area of Freedom, Security and Justice.

The introduction of mutual recognition to the criminal law field was underpinned by the emphasis on non-interference with national criminal justice systems. Mutual recognition was proclaimed in order to avoid stagnation in the development of an Area of Freedom, Security and Justice caused by the resistance of Member States against supranational EU criminal law. ${ }^{119}$ It is, however, contradictory to pursue the establishment of a single judicial area, on the one hand, and to reassure Member States that they can preserve criminal law as the sharp end of national sovereignty, on the other. This ambivalence is well reflected in the mutual recognition instruments which contain diverging conditions for the application of mutual recognition. In particular, the exemptions from mutual recognition vary greatly. ${ }^{120}$ Exemptions from mutual recognition reflect the desire of Member States to protect national control and interests in certain fields. The present diversity is not only incompatible with the idea of a single area of justice, but it also simultaneously curtails the fundamental rights of persons affected by mutual recognition measures and complicates the work of practitioners.

It has therefore been argued that improving the functioning of mutual recognition requires a certain consensus on the substantive rules to be mutually recognised and enforced. ${ }^{121}$ It is wrong to believe that mutual recognition is a neutral policy tool that only addresses the procedure to be followed in cooperation between national criminal justice systems while it leaves national substantial standards intact. Mutual recognition must be, therefore, indispensably accompanied by harmonising measures.

This conclusion applied to the future creation of the EPPO means that it is unrealistic to expect that the EPPO can rely on mutual recognition for evidence

\footnotetext{
${ }^{119}$ K. Ligeti, The principle of mutual recognition - prerequisites, principles and exemption, in: Proceedings of the $5^{\text {th }}$ European Jurists Forum, Budapest, 2009, p. 55-72.

${ }^{120}$ The most striking example is the European Evidence Warrant, where, for example, Germany succeeded in "opting-out" from mutual recognition. Germany made the acceptance of the framework decision dependent on the condition that it can "reapply" double criminality for a number of offences featured on the list if it is necessary to carry out search and seizure for the execution of the warrant. Declaration of the Federal Republic of Germany, Framework Decision 2008/978/JHA of $18^{\text {th }}$ December, 2008, on the European evidence warrant for the purpose of obtaining objects, documents and data for use in proceedings in criminal matters, OJ No. L 350, 30 $0^{\text {th }}$ December, 2008 , p. 92.

${ }^{121}$ V. Mitsilegas, EU Criminal Law, Hart Publishing, Oxford, 2009, p. 124.
} 
gathering and the admissibility of evidence as suggested in the Green Paper and in the Spanish proposal. This would mean, namely in practice, that the EPPO - and its delegates - would carry out investigative measures according to the domestic laws of the respective Member States. The evidence gathered this way would then be mutually admissible in prosecutions lead by the EPPO. Based on the current experiences of mutual recognition, it is hard to expect that Member States will be willing to recognise and admit evidence which was gathered in other Member States based on substantially different standards. ${ }^{122}$

Resistance towards the mutual admissibility of evidence is understandable in light of the differences between the national systems of investigation and prosecution of the Member States. The preliminary findings of the comparative study on the "EU model rules of criminal investigation and prosecution for the procedure of the proposed European Public Prosecutor's Office" show that the regulation - if any - of evidence gathering differs significantly from one Member State to another leaving room for forum shopping in practice.

The divergence between the national laws of the Member States is especially striking in relation to special investigation techniques. ${ }^{123}$ It is often the case that whereas a certain special investigation technique is strictly regulated in some Member States, it is not regulated at all in others. The lack of regulation in the Member States does not mean that the measure is not used in practice, but rather encompasses a series of different scenarios. The law, for example, permits the investigating authorities to apply such practices as long as it does not violate other rules $^{124}$, or that the investigative authorities may use such practices with the help or under the umbrella of another measure or by the combination of several measures, ${ }^{125}$ or simply that the measure is used by the investigative authorities in a grey

122 The reluctance of the Member States is well illustrated by the burdensome and still ongoing negotiations on the European Investigation Order - Initiative for a Directive of the European Parliament and of the Council regarding the European Investigation Order in criminal matters, Interinstitutional File: 2010/0817 (COD), 29 ${ }^{\text {th }}$ April, 2010.

${ }^{123}$ For a description of special investigative techniques see $J$. A. E. Vervaele, Special procedural measures and the protection of human rights, General report for Section III of the AIDP, RIDP 2009/1-2, p. 75-123.

${ }^{124}$ E.g. data mining (the process of extracting patterns from data) and profiling (forensic profiling) is always possible in some Member States (J. Zezulová, M. Růžička, National report for the Czech Republic, "Criminal investigation and prosecution of crimes affecting the financial interests of the EU", manuscript, 2011, p. 64-66; J. Ginter, National report for Estonia, "Criminal investigation and prosecution of crimes affecting the financial interests of the EU", manuscript, 2011, p. 86 - 90; T. Kastula, National report for Finland, "Criminal investigation and prosecution of crimes affecting the financial interests of the EU", manuscript, 2011, p. $82-85$; A. Binet-Grosclaude, National report for France, "Criminal investigation and prosecution of crimes affecting the financial interests of the EU", manuscript, 2011, p. 129 - 174; M. Schiltz, National report for Luxembourg, "Criminal investigation and prosecution of crimes affecting the financial interests of the EU", manuscript, 2011, p. 28 - 29; S. Steinborn, National report for Poland, "Criminal investigation and prosecution of crimes affecting the financial interests of the EU", manuscript, 2011, p. 65 - 67; A. Nicolae, C. Dumitrescu, National report for Romania, "Criminal investigation and prosecution of crimes affecting the financial interests of the EU", manuscript, 2011, p. $112-118$; P. Gorkič, National report for Slovenia, "Criminal investigation and prosecution of crimes affecting the financial interests of the EU", manuscript, 2011, p. 79 - 81; L. Bachmaier, National report for Spain, "Criminal investigation and prosecution of crimes affecting the financial interests of the EU", manuscript, 2011, p. 57 - 60; P. Howse, National report for England and Wales, "Criminal investigation and prosecution of crimes affecting the financial interests of the EU", manuscript, 2011, p. 52 - 55) provided none of the data is specially protected by law.

125 E.g. tracking and tracing of objects and persons is not regulated in Luxembourg, Sweden and England and Wales (M. Schiltz, National report for Luxembourg, "Criminal investigation and prosecution of crimes affecting the financial interests of the EU", manuscript, 2011, p. 27 - 28; Ch. Wong, National report for Sweden, "Criminal 
zone of lawlessness. ${ }^{126}$ And there are, of course, cases where a certain measure is not allowed by criminal procedural law in a given Member State and information obtained this way is not admissible in evidence. ${ }^{127}$

Even these few examples demonstrate that the differences of the criminal procedures of the Member States are so substantial that the EPPO cannot rely on the investigative measures of the territorial state for its supranational investigations; it will need its own set of harmonised supranational investigative powers for gathering evidence.

At the same time, it does not mean that mutual recognition would have no place in the future design of the functioning of the EPPO. Mutual recognition will still be necessary for the functioning of judicial warrants authorising certain investigative measures (a warrant obtained for certain investigative measure should be mutually recognised in the whole territory of the EU). It is also conceivable that those investigation measures, where the convergence between the national laws of the Member States is greater, ${ }^{128}$ will function on the basis of mutual recognition.

investigation and prosecution of crimes affecting the financial interests of the EU", manuscript, 2011, p. 45 - 47; $P$. Howse, National report for England and Wales, "Criminal investigation and prosecution of crimes affecting the financial interests of the EU", manuscript, 2011, p. 50 - 52), but may be carried out by way of surveillance; on-line search of computers is not regulated in Estonia and Lithuania (J. Ginter, National report for Estonia, "Criminal investigation and prosecution of crimes affecting the financial interests of the EU", manuscript, 2011, p. 100 - 106; G. Švedas, National report for Lithuania, "Criminal investigation and prosecution of crimes affecting the financial interests of the EU", manuscript, 2011, p. 92 - 94), but may be practised under covert surveillance or telecom surveillance rules; monitoring of bank transactions does not exist in Poland, Lithuania, Spain and Sweden $(S$. Steinborn, National report for Poland, "Criminal investigation and prosecution of crimes affecting the financial interests of the EU", manuscript, 2011, p. 65; G. Švedas, National report for Lithuania, "Criminal investigation and prosecution of crimes affecting the financial interests of the EU", manuscript, 2011, p. $72-76 ;$; L. Bachmaier, National report for Spain, "Criminal investigation and prosecution of crimes affecting the financial interests of the EU", manuscript, 2011, p. 54 - 57; Ch. Wong, National report for Sweden, "Criminal investigation and prosecution of crimes affecting the financial interests of the EU", manuscript, 2011, p. 43 - 45), but information constituting bank secret may be obtained through a production order in these countries.

${ }^{126}$ E.g. tracking and tracing of objects and persons in Poland, Italy, Spain (S. Steinborn, National report for Poland, "Criminal investigation and prosecution of crimes affecting the financial interests of the EU", manuscript, 2011, p. 65; F. Ruggieri, National report for Italy, "Criminal investigation and prosecution of crimes affecting the financial interests of the EU", manuscript, 2011, p. 53 - 55; L. Bachmaier, National report for Spain, "Criminal investigation and prosecution of crimes affecting the financial interests of the EU", manuscript, 2011, p. $57-60$ ).

${ }^{127}$ E.g. on-line search of computers is not allowed in Finland, Luxembourg and in the Netherlands (T. Kastula, National report for Finland, "Criminal investigation and prosecution of crimes affecting the financial interests of the EU", manuscript, 2011, p. 95 - 97; M. Schiltz, National report for Luxembourg, "Criminal investigation and prosecution of crimes affecting the financial interests of the EU", manuscript, 2011, p. 32 - 33; I. Peçi, National report for the Netherlands, "Criminal investigation and prosecution of crimes affecting the financial interests of the EU", manuscript, 2011, p. $81-83$ ) and is expressly forbidden in Poland, Germany and Italy (S. Steinborn, National report for Poland, "Criminal investigation and prosecution of crimes affecting the financial interests of the EU", manuscript, 2011, p. 74; B. Hecker, National report for Germany, "Criminal investigation and prosecution of crimes affecting the financial interests of the EU", manuscript, 2011, p. $77-83$; F. Ruggieri, National report for Italy, "Criminal investigation and prosecution of crimes affecting the financial interests of the EU", manuscript, 2011, p. 66 $-68)$.

${ }^{128}$ There are many similarities between the Member States in regulating the conditions of traditional investigation measures such as pre-trial interrogation of witnesses, arrest of the suspect and detention for questioning, pre-trial custody, access to relevant premises, search and seizure, invoking experts pre-trial. 


\section{Concluding remarks}

The above, short outline of the history of the EPPO summarised almost fifteen years of scientific and policy argumentation. Different models have been put forward for setting up the EPPO and extensive debate surrounded both the need and feasibility of such an institution as well as the crucial aspects of its functioning. The discussion focused on the structure and powers of the EPPO, its relation to European and national actors in the criminal justice field, its mandatory or discretional prosecution and the accountability for discretional powers, the definition of harmonised investigation measures and the list of investigation measures subject to mutual recognition, the ex ante and ex post review of the activities of the EPPO and the status and powers of the judge of freedoms, the jurisdiction rules for investigation and prosecution, the rules on the admissibility of evidence and the protection of fundamental rights. These arguments will remain relevant in shaping the implementation of Art. 86 TFEU.

Art. 86 TFEU leaves it entirely down to future regulation on the EPPO to define the rules applicable to its procedure. Hence it is up to future regulation to mark those investigation and prosecution measures where, on the one hand, the EPPO need to have a harmonised set of supranational rules and those which, on the other, may be left to the regulation of national criminal procedure and should be subject to mutual recognition. Art. 86 TFEU does not predefine the EPPO's model. This open-endedness certainly represents a challenge for the implementation, in particular for those aspects, on which Art. 86 TFEU is silent. 